\title{
Sources and types of change: a study with three English teachers ${ }^{1}$ \\ Fontes e tipos de mudança: Um estudo com três professores de inglês
}

Rosane Rocha Pessoa*

Universidade Federal de Goiás

Maria Aparecida Yasbec Sebba**

Universidade Federal de Goiás

\begin{abstract}
Based on the assumption that change is more likely to happen if it is not imposed upon teachers, but rather developed by them, we invited three English teachers to take part in a study in which they would have the opportunity to reflect collaboratively upon their teaching. Based on these reflections, some themes were defined for theoretical readings, which also became objects of reflection. The analysis of the eight reflective sessions and the final interview allowed us to detect eight sources of declared changes. The results showed that experiences which belong to the realm of practice are more relevant than theory to foster teacher change and that changes seem to have happened both cognitively and behaviorally. In addition, the more experienced teachers performed changes that were more "reflective" than "technical", confirming that less experienced teachers are more worried about the technicalities of teaching while more experienced or reflective teachers are more concerned with the consequences of what they do to students.
\end{abstract}

KEYWORDS: teacher change, reflection, teacher education.

RESUMO: Partindo do pressuposto de que mudanças são mais prováveis de acontecer quando não impostas aos professores, mas, sim, desenvolvidas por eles, convidamos três professoras de inglês para participar de um estudo no qual elas teriam oportunidade de refletir colaborativamente sobre as suas práticas pedagógicas. Com base nessas reflexōes, foram definidos tópicos para a realização

\footnotetext{
* pessoarosane@gmail.com

** yasbec@ih.com.br

${ }^{1}$ We are thankful to Ana Maria Ferreira Barcelos (Universidade Federal de Viçosa) for problematizing the theoretical background of this text, which resulted in some alterations. However, any errors of misjudgment or oversight in the text are solely our responsibility.
} 


\begin{abstract}
de leituras teóricas, as quais também foram objetos de reflexão. Os resultados mostraram que as experiências que pertencem ao domínio da prática foram mais relevantes do que a teoria para fomentar a mudança das professoras, e as mudanças parecem ter acontecido tanto comportamental quanto cognitivamente. Além disso, as mais experientes realizaram mais mudanças "reflexivas" do que "técnicas", confirmando que professores menos experientes estão mais preocupados com os aspectos técnicos do ensino, ao passo que os mais experientes ou reflexivos focalizam mais as consequências de suas ações para os alunos.

PALAVRAS-CHAVE: mudança do professor, reflexão, formação de professores.
\end{abstract}

\title{
A context which lends itself to teacher change
}

A review of the literature on teacher change shows that it is characterized by three central elements: it is related to learning and development; it is a complex process which presupposes the interaction between personal and contextual factors; and, finally, it is an interactive and multidimensional process which includes cognitive and behavioral changes and the articulation between them. It also shows that changes may be more acceptable if they are not imposed upon teachers, but rather developed by them.

Based on these assumptions, we invited three English teachers who worked at the language center of the Universidade Federal de Goiás to develop a study in which they would have the opportunity to reflect collaboratively upon their teaching. Through the analysis of their perceptions of the changes that happened in their thinking and actions as a result of participating in the reflective sessions, we aimed at examining the kind of experiences which caused the declared changes, the number of declared changes caused by these experiences, and the types of declared change. By "declared changes" we mean the teachers' comments suggesting that something was altered in their thinking or actions.

These objectives were established, first, because we wanted to find out if practice, as a stepping stone, is more powerful than theory in order to promote teacher development (SMYTH, 1991). Secondly, because we believe that the more relevant type of change is the one that brings about action which in fact improves knowledge construction in class or students' learning results, or yet promotes the problematization of values such as democracy, justice, respect for differences, and compassion. As Dewey ([1910]1997) contends, what matters are the consequences of what we do.

During the research period, the three instructors were teaching English at the language center, and were also doing the undergraduate course of English and Portuguese teacher education at the same university. Though they were 
also student-teachers, here they will simply be called "teachers"2 since, at the language center, teachers are totally responsible for the groups and they are paid to do the job. To become teachers at the language center, they first take a test, which consists of two phases: an essay-writing exam and a lesson. Then, they take a 60-hour teaching training course, at the end of which they give another lesson and are selected based on three criteria: communication skills, teaching techniques, and pedagogical reasoning skills and decision-making. After they start teaching, they are continuously counseled by the language professors of the college, a role which is also played by the authors of this article.

The aim of the language center is to help students to develop their communicative competence by means of the instruction of the four skills. As may happen in different foreign language teaching contexts, the language center faces challenges such as: most teachers are inexperienced, class-size varies from fifteen to twenty-seven students; classes are heterogeneous, and the level of communicative competence reached by students during the four years of the course is unsatisfactory. Thus, it becomes a very rich context for research, especially on teacher change, since there is so much room for improvement.

\section{Teacher change: an inside perspective}

The theme of teacher change can be approached from a macro perspective and from a micro perspective. A teacher education program promoted by an organization is an example of the macro perspective; while a teacher education group, which is the case of this research, is an example of the micro perspective. The difference between them is that, in the former, changes are normally mandated or suggested by others and, in the latter, they tend to be more spontaneous. Some studies on teacher change show that when change is mandated, teachers tend to resist it, but when they follow their own sense of what their students need and what is working and when they have opportunity to explore and choose, they undertake change voluntarily (RICHARDSON, 1998).

Nevertheless, Richardson (1998, p. 5) points out that the changes teachers make individually may "perpetuate practices based on questionable assumptions and beliefs", and that is the reason why some direction may be

${ }^{2}$ They will also be called "participants" when referring to their role in the research developed. 
helpful. In this study, guidance was given by watching the video of the participants' own classes and by the collaborative reflection ${ }^{3}$ on these classes and on texts whose themes were selected from the discussions held in the reflective sessions. Although the group was formed for the purpose of the research, we believe that change happened as a result of what they perceived as necessary. As researchers, we did not have an agenda for the teachers to follow; on the contrary, they established this agenda by themselves, once the teacher whose class had been observed started the discussion and the others joined it. Eventually we also took part, giving our opinions and posing questions about the topics raised, but rarely suggesting new practices.

Change is defined in the literature as differences shown in teachers' thinking and acting (PENNINGTON, 1995; RICHARDSON, 1998; GUSKEY, 2002; BORG, 2003; SIMÃO; CAETANO; FLORES, 2005). According to Pennington (1995, p. 705), "teacher change is behavioral and perceptual, that is, attitudinal and cognitive". She cites Freeman (1989) to highlight that awareness of the need to change - or at least the desirability of experimentation - is the key ingredient to teacher change. Some questions arise from Pennington's statement: how do behavioral and perceptual changes relate? Does behavioral change presuppose perceptual change? Does perceptual change imply behavioral change?

After reviewing nine research studies about teacher cognition and teacher education, Borg (2003) concludes that behavioral change does not imply cognitive change, and the latter does not guarantee changes in the former. This conclusion may have been reached because the studies reviewed fit into formal teacher development contexts, whether it be in teacher training courses or university courses, which, even if adopting less traditional forms of teacher education, require certain standards and normally have assessment as part of the program. As a result, student teachers may have behaved so as to conform to these standards, and in this case changes in action do not imply changes in thinking.

However, in teacher development experiences, in which desired outcomes are not predetermined and teachers are free to collaboratively look for their own routes of inquiry and move towards the articulated end of improving student learning, changes in both their behavior and thinking are

\footnotetext{
${ }^{3}$ We understand "reflection" as entailing "active, persistent, and careful consideration of any belief or supposed form of knowledge in the light of the grounds that support it, and the further consequences to which it tends" (DEWEY [1910]1997, p. 6).
} 
likely to occur. This view is in keeping with Fullan (1991), who contends that change is a reciprocal process between behavior and beliefs. But how do these changes occur? Do they first happen cognitively or behaviorally? Guskey (2002) believes that, because teachers are pragmatic, change is first behavioral, that is, it happens in teachers' classroom practice, it alters students' learning results, and then teachers change their beliefs and attitudes. This description defines what Guskey calls a "model of teacher change", which finds support in Bolster's study (1983, cited in GUSKEY, 2002, p. 384) since it demonstrates that "experienced teachers seldom become committed to a new instructional approach or innovation until they have seen it work with their students".

Pennington (1995) also depicts lasting change in teachers' behavior "as a result of trying something new, reflecting on its consequences, and then trying it again with alterations as needed or desired" (p. 706). Based on an investigation with eight Hong Kong secondary teachers' adoption of innovative practice, the author also proposes the following explanation about teacher change:

Teachers typically move through a change cycle in responding to an innovation in which their focus shifts over time from its procedural aspect, to its interpersonal aspect, and finally to its conceptual aspect. Through this process, they achieve a higher level of expertise, psychological comfort, and understanding of the innovation, thereby personalizing it to bring it into their own practice (p. 705).

Pennington (1995) describes the procedural category as matters involving techniques, material and logistics; the interpersonal category as matters involving the teachers' and the students' reactions, feelings, roles and responsibilities, motivation, and classroom atmosphere; and finally the conceptual category as matters involving personal meaning, explanation, and integration of theory and practice. She believes this sequence represents a natural and possibly a relatively common path, though not a necessary sequence, as other teacher change studies cited by her have shown.

Because the focus of this investigation is not only on teachers' cognitions but also on teachers' practice, one last question that should be asked here is: which cognitions shape teachers' practice? Although teachers' cognition has been described in various ways (BREEN; HIRD; MILTON; OLIVER; THWAITE, 2001; GATBONTON, 1999; JOHNSON, 1992), Borg (2003) asserts that two contrasting perspectives support these studies: one derives from the educational literature on decision-making and the other from literature on teachers' personal practical knowledge. The first adopts a "somewhat technicist 
view of teaching" (p. 93) while the second "examines teaching more holistically, taking into account, for example, the role of affective, moral and emotional factors in shaping teachers' classroom practices" (p. 93).

Since change is the focus of this article, we were interested in the types of cognition that shaped it. If the participants' cognitions, when talking about change, were related to teachers' factors, or if they were related to the lesson in terms of a "segment of instruction" (RICHARDS, 1998, p. 72), they were considered "technical". By teachers' factors we mean classroom management, teacher's manner, instructions, and language. The lesson as a segment of instruction includes steps, structuring, task types, and pacing. If, on the other hand, the teachers mentioned change taking the learners into consideration, focusing on students' affective factors, participation, extent and quality of language use, we called this type of cognition "reflective". The term "reflective" was used when teachers' attention was directed to the consequences of their teaching practice, that is, when they changed because they reflected on the value and goals of what they were doing for the students. These terms are in accordance with Bartlett (1990), when he defends that teachers have to go beyond the "how" to do things to the "what" and "why" of the educational process, that is, from the technical side of teaching to the reflective one to become a critically reflective teacher.

\section{Background to the research}

The students who enter the English and Portuguese teacher education course at the Universidade Federal de Goiás are of mixed-ability. Some of them already have a good level of English, and others develop their language skills during the course. The most proficient ones normally become teachers at the language center and can only teach there while they are regular students of the college.

The English course at the language center lasts four years and is organized in semesters, from English I to English VIII. Classes are twice a week from Monday to Thursday and last 1 hour and 40 minutes, comprising a total of 60 hours. Courses are offered in the afternoon and evening, and the students are university professors, employees, and students, as well as people from the community.

All thirteen of the English teachers who taught at the language center in 2003 were invited to take part in the research, but only three female teachers volunteered. From now on, they will be called by the fictitious names Penélope, Júnia, and Lavínia. Penélope and Júnia were Rosane’s supervisees, 
and Lavínia was Maria Aparecida's. The supervisor is in fact a mentor, who helps and mediates the teachers' development. The mentor's role is to provide ongoing assistance and support in the preparation of lessons and students' assessment, and also to observe at least two lessons during the semester, so that they can become objects of reflection aiming at improved instructional practice and professional performance.

The following table presents the characteristics of the teachers:

TABLE 1

Characteristics of teachers in the year of the research (2003)

\begin{tabular}{|c|c|c|c|c|c|c|}
\hline Teachers & Sex & Age & $\begin{array}{l}\text { Year at the } \\
\text { undergraduate } \\
\text { course }\end{array}$ & $\begin{array}{l}\text { Teaching experience } \\
\text { (four skills) }\end{array}$ & $\begin{array}{l}\text { Experience at the } \\
\text { language center }\end{array}$ & $\begin{array}{l}\text { Group } \\
\text { video } \\
\text { recorded }\end{array}$ \\
\hline Penélope & F & 22 & $4^{\text {th }}$ & - & $1^{\text {st }}$ semester & English III \\
\hline Júnia & $\mathrm{F}$ & 23 & $5^{\text {th }}$ & 1 year & $2^{\text {nd }}$ semester & English I \\
\hline Lavínia & $\mathrm{F}$ & 30 & $3^{\text {rd }}$ & 12 years & $3^{\text {rd }}$ semester & English IV \\
\hline
\end{tabular}

\section{Research activities and data}

Data started being collected in May and stopped being gathered in November 2003. Believing in the "practicality ethic of teachers" (DOYLE; PONDER, 1977, cited in PENNINGTON, 1995, p. 720), our study was designed to have the participant teachers' lessons trigger the need for academic theory and change in their practice and personal theories. ${ }^{4}$ Thus, the instruments used were:

- initial questionnaire: to provide personal information about the teachers;

- video recording of six lessons: to stimulate reflective sessions;

- texts: to stimulate reflective sessions;

- audio recording of eight reflective sessions: to provide primary data for analysis;

- final questionnaire: to evaluate the experience of participating in the research.

${ }^{4}$ The term "personal theories" is used here meaning "the knowledge teachers have about teaching" (PESSOA; SEBBA, 2006), which we believe to have the same status of the knowledge generated by academics. 
These were the procedures:

1) a lesson was video recorded by a researcher;

2) the video of the whole lesson was watched by the group of three teachers and two researchers as a stimulus for reflection;

3) the teacher who had taught the observed lesson described its main steps and made the first comments;

4) the reflective session started with comments, questions, and suggestions from the other members of the group;

5) at the end of the reflective session, the teachers chose a topic that had raised the most reflections, about which some texts would be read.

In the first phase, this procedure was followed three times, one for each teacher, in three different sessions. After that, we had three topics to read about: "oral production", "teacher talking time", and "pace". One session was devoted to the reflection upon these topics, stimulated by the texts read by the group. In the second phase, three other lessons were video recorded and the same procedures were adopted, the following being the topics chosen: "presentation", "pronunciation", and "affective factors". Altogether, there were eight reflective sessions, six stimulated by the lessons and two, by the texts.

The transcription of the eight reflective sessions and the final interview became the primary research data. These two documents were, first, subjected to content analysis so that all the segments concerning change mentioned by the participants were selected and their sources and types of change detected, and then these data were quantified. The transcriptions used in this article were translated into English as faithfully as possible. The Portuguese version of the transcriptions is given in footnotes.

\section{Sources of change}

Two sources of change were found in the data. The first resulted from the four research experiences - "self-observation", "peer-observation", "theory" and "reflective sessions". The term "self-observation" was used to refer to the moments when the participants mentioned they had changed as a result of what they had seen in the video of their own classes, as in the following example: 
I changed correction after watching my lesson, and my focus was on their production ${ }^{5}$ (Lavínia $\left.-4 \mathrm{M}-04 / 07 / 2003\right) .{ }^{6}$

The second research experience was called "peer-observation" and was used when the participants described change originating from what they had observed the other participants doing in the video recording of their lessons:

After I started watching Lavínia's and Júnia’s classes, the issue of having students [English III] speak more improved a lot. Now they ask [before they didn't], "How can I say this? What's this?"7 (Penélope - 3M 27/06/2003).

"Theory" was the third research experience and was used when the participants reported a change that had come about after reading the texts proposed either by the researchers or the participants themselves, as in this example:

This text is very good, especially these categories. They're things you perceive, but you think you're drifting away, but when you read, "the guy said, so it's true." [...] the question of the student's ego, of the idea that we have that the extrovert is the good student and the shy student is the bad one, that he's quiet, because the student who doesn't speak hasn't learnt. This semester I could see it's not true. [...] And after I read this text I stopped to think, this idea that we have that the "communicative", the "outgoing" of the class, it's not this way ${ }^{8}$ (Penélope - 8M - 18/12/2003).

\footnotetext{
${ }^{5}$ Eu mudei a correção por ter assistido à [minha] aula, e o meu foco estava na produção deles.

${ }^{6}$ These references contain the name of the participant, the number of the meeting (4M: fourth meeting) and the date when it occurred.

${ }^{7}$ Depois que eu comecei a assistir as aulas da Lavínia e da Júnia, melhorou bastante essa questão deles [seus alunos do nível Inglês III] falarem mais. E eles já perguntam, antigamente eles não perguntavam de jeito nenhum, "How can I say this? What's this?".

${ }^{8}$ Esse texto é muito bom, principalmente essas categorias aqui. [...] São coisas que você percebe, mas acha que está viajando demais, mas quando você lê, "o cara falou, então é verdade". [...] a questão do ego do aluno, da ideia que a gente tem que o aluno extrovertido é o bom aluno e o tímido é o mau aluno, que é quietinho, porque o aluno que não fala não aprendeu. E esse semestre eu pude ver que isso não é verdade. [...] E depois que eu li esse texto é que eu fui parar para pensar, essa ideia que a gente tem de o "comunicativo", o "outgoing" da turma, não é bem assim.
} 
The last research experience consisted of the "reflections" that emerged from the participants while they were commenting on what they had read or seen on the video. They elaborated on what was commented on during the sessions. In the example that follows, Penélope's process of reflection can be seen:

I very often make my students do crazy things in my class. [...] I used to do it with my students. I used to; today, I don't anymore. And in that class that was filmed, the students got red when they got the hot potato and I thought, "is it really necessary to expose students that much?” I don't think so; they can do well with less anxiety $(8 \mathrm{M}-18$ / 12/2003).

Later on, at the end of the session, Penélope reaches a conclusion:

I would go on doing it [hot potato], but I wouldn't ask my student to do as many crazy things as I used to do, [...] though for me they're $\mathrm{OK}$, but they can be hard for the student. For example, the fashion show for a man, there was a skirt, and it was the only item of clothing left [the students had to put on the clothes the teacher had brought so that they could be described their classmates] and I said "X [a male student], put it on," and he answered, "Are you crazy? I'll never do that in my life." For me, it was OK, but for him to wear a skirt was hell. Today I can respect them [the students], but had it been some time ago, I would have insisted. I wouldn't do it today, but taking a piece of paper [as they do in the activity hot potato] and speaking is part of the lesson. If they're there, they have to speak ${ }^{10}(8 \mathrm{M}-18 / 12 / 2003)$.

\footnotetext{
${ }^{9}$ Eu faço meu aluno pagar mico demais da conta na minha aula. [...] Eu fazia isso com os meus alunos, fazia, hoje não faço mais. E aquela aula que foi filmada, que os alunos ficaram vermelhos na hora da batata quente, depois que eu fui ver, "será que tem necessidade de expor o aluno tanto?" Acho que não precisa, ele pode render sem tanta ansiedade envolvida.

${ }^{10}$ Eu continuaria fazendo [hot potato], só que eu não faria o meu aluno pagar tanto mico quanto eu fazia há algum tempo atrás, [...] que para mim não tem problema nenhum, mas para ele aquilo é impossível. Por exemplo, o desfile, para um homem, tinha uma saia, e era a única peça de roupa que tinha sobrado, aí eu brinquei, "X [aluno], põe a saia", e ele respondeu, "está louco, não ponho um negócio desse nunca na minha vida". Para mim, não tinha nada, mas para ele botar uma saia é o fim. Hoje eu consigo respeitar, mas algum tempo atrás, eu ia insistir. Hoje, não, mas pegar um papel e falar faz parte da aula. Se o menino está lá, ele tem que falar.
} 
Besides these four research experiences, other sources from real life experiences were also detected as being catalysts for change, namely "the participants' mentors", "their peers", the "input sessions" they attended at the language center, and "the participants' own experience as teachers". In the following paragraphs, these other four experiences are explained and exemplified.

Each teacher at the language center has a "mentor", a professor from the college, who s/he sees regularly to discuss the lesson plans and the problems faced in the classroom. This mentor also attends some of the teachers' classes so that then they can talk about them. The teachers seem to learn from "mentoring" as well, as can be seen below:

The question is interesting because it was something we noticed in a class that wasn't filmed, but Rosane observed, and my tendency was this. I thought my presentation shouldn't be short, or I wouldn't be able to clarify things to them, but what I noticed was that most of the presentations that I dragged - because in my plan it was just 10 minutes - were long, and the students' doubts appeared when they practiced. Therefore, presentation time doesn't have to be long for elementary levels. I noticed I was trying to anticipate their doubts, I knew they'd have doubts, and I wanted to solve them in the presentation $^{11}$ (Júnia - 4M-04/07/2003).

Besides this mentor-teacher relationship, teachers at the language center usually share classroom materials, ideas, concerns and problems with their "peers". This exchange contributes to their development and gives them confidence as they frequently see that they are not alone, that their peers understand them because they deal with similar problems. They trust their "peers" and learn from them. This was considered another source of change as was mentioned by two participants. Below we can see one example:

\footnotetext{
${ }^{11}$ A pergunta é interessante porque foi uma coisa que a gente observou numa aula que não foi filmada, mas que a Rosane assistiu, e a minha tendência era essa. Eu achava que a minha apresentação não poderia ser curta, porque eu não conseguiria esclarecer as coisas para eles, mas o que eu vi é que a maioria das apresentações que eu alonguei, porque no plano estava lá 10 minutos, eram longas e as dúvidas surgiam na hora deles praticarem. Então o tempo de apresentação não precisa ser longo para o nível baixo. Eu vi que eu estava tentando adiantar a dúvida deles, sabia que ia ter dúvida e queria resolver na apresentação.
} 
One day, $\mathrm{T}$ [a teacher at the language center] said, "he [the student] has to see that $50 \%$ is his [responsibility], and he has to go for it." So, my pace wasn't good, and I had to speed up, but I also showed their responsibilites. [...] If, after the first test, [the student] can't keep up with the group, then there is a problem. I told them, "go study the other files." I learnt with what T said, " $50 \%$ depends on them" 12 (Lavínia-8M-18/12/2003).

Another experience detected from the data, not one derived from the research instruments, were the "input sessions" the language center usually holds each semester. These sessions, on topics of teaching interest, are given by the professors of the college or by the language center teachers themselves. This experience was mentioned by Lavínia, who, after an input session about pronunciation intelligibility, is in conflict with what she now sees in her peer's class, what is discussed in the reflective sessions, and what she had seen in the input session about Communicative Language Teaching (CLT). Her personal theory of intelligibility is threatened. Two theories (her peer's understanding that the students' pronunciation deserves especial attention from the teachers and the concept of intelligibility in CLT) were in conflict and generated instability in her own personal theory:

At the end I say, "do they have pronunciation problems? Yes," and they know they have, but I don't usually tell them. [...] After the input sessions [provided by the language center about CLT], I'm in doubt because, in the communicative approach, should I leave pronunciation aside? Do I just want the students to be able to communicate? I don't know if it's good for them, if this is what they are expecting $^{13}$ (Lavínia - 4M-04/07/2003).

\footnotetext{
${ }^{12}$ Um dia, a P [uma professora do centro de línguas] falou assim, "ele [o aluno] tem que ver que $50 \%$ é dele e ele tem que correr atrás. Então, o meu tempo não estava bom, e eu tive que acelerar mais, mas eu joguei muito para eles também. [...] Se depois da primeira prova, [o aluno] não está acompanhando, então tem algum problema. O que eu fiz foi jogar para eles, "vai estudar os outros files". Então eu peguei o que a $\mathrm{P}$ falou, "joga os $50 \%$ para eles".

${ }^{13}$ No final, eu falo, "tem problema de pronúncia? Tem," e eles sabem que têm, mas eu não costumo parar e apontar onde que está. [...] Depois das input sessions [sessões pedagógicas realizadas pelo centro de línguas sobre o ensino de língua comunicativo], eu fico no meio do caminho, porque na abordagem comunicativa eu devo deixar a pronúncia de lado? Eu quero só que ele consiga se comunicar? Eu não sei se isso é bom para ele, se é isso que ele está esperando.
} 
"Teacher experience" was the last source of change found in the data (only in Júnia's data), and it can be explained as the teacher's own thoughts and knowledge resulting from classroom events and validated by teaching practice (TARDIF; RAYMOND, 2000). Her experience as a teacher helps her to make choices about what to teach or how to deal with students, as in the following transcript:

I think it's very important to teach the phonemic symbols and [...] I only learnt them better when I had to teach them. I transcribed the words and I still do it because we have some difficulty with pronunciation every time we see a new word ${ }^{14}$ (Júnia - 4M - 04/07/2003).

As expected, changes happened differently in each participant. The following table shows the eight experiences that originated change and the number of change for each participant brought about either by the research experiences or by experiences outside the research. Penélope's declared changes were 20, all of which were motivated by the research experiences. Lavínia’s changes totaled 25, 22 of which resulted from the research experiences and 3 from experiences outside the research. Finally, from Júnia's speeches, 15 changes were detected, 7 caused by the research experiences, and 8 caused by experiences outside the research.

TABLE 2

Number of change for each participant by experiences within/outside the research

\begin{tabular}{l|c|c|c|c}
\hline & Penélope & Lavínia & Júnia & Total \\
\hline Self-observation & 11 & 8 & 3 & 22 \\
Theory & 6 & 4 & 3 & 13 \\
Peer observation & 2 & 8 & 1 & 11 \\
Reflection & 1 & 2 & & 3 \\
Input sessions & & 1 & & 1 \\
Peers & & 1 & 1 & 2 \\
Mentoring & & 1 & 4 & 5 \\
Teacher Experience & & & 3 & 3 \\
\hline
\end{tabular}

\footnotetext{
${ }^{14} \mathrm{Eu}$ acho muito importante ensinar os símbolos e [...] e eu só fui aprender melhor quando eu tive que dar aula dos símbolos. Eu pegava as palavras e transcrevia e até hoje eu pego para transcrever, porque a dificuldade de pronúncia a gente vai ter com toda palavra nova.
} 
TAB. 2 shows that "self-observation" proved to be a rich experience to encourage change, especially for Lavínia and Penélope, who were the most affected by the research experiences. It demonstrates that the impact of seeing oneself is powerful. The teacher is neither told what happened, nor what should or should not be changed. She can see and reflect on what happened, draw conclusions and take action to change what was not satisfactory. In the final interview, Lavínia confirms: "observing my own lessons was 'very' important because I saw with other eyes what was happening in my class (her emphasis)." ${ }^{\prime 5}$ And Penélope also recognizes its relevance:

When you're in class, you're not conscious of what you're doing, you don't think a lot about the process itself, but when there is somebody looking at you, [...] you think, "I made this and that mistake", you're more aware, but when you see yourself, you see what you did right or wrong, it's totally different. When the mentor says, you think, "he says that because he's fussy, he's a teacher and he knows it all", but it's no the same thing as building your own knowledge, you can see it, "I made a mistake; I'm saying too much OK". One thing is to listen to the mentor tell you "you're saying too much OK", another is to observe it; it seems that the mistake becomes bigger. For me, it was a great experience $^{16}$ (FI - 19/12/2003).

However, while Penélope made more changes as a result of the "theory", Lavínia was more influenced by "peer observation", influence which equaled "self-observation". It is explained by the importance theory has for Penélope:

The readings [for the research] were very good. I learnt a lot. One example of how the readings helped me was in the oral test, that

\footnotetext{
${ }^{15}$ [...] a gravação foi "muito" importante porque eu vi com outros olhos o que estava acontecendo dentro de sala [ênfase de Lavínia].

${ }^{16}$ Quando você está em sala, você não tem consciência do que você está fazendo, não pensa muito no processo em si, mas quando tem uma pessoa te olhando, [...] você já pensa, "eu errei aqui, eu errei ali", você já fica com a antena ligada, mas quando você se vê, você vê o seu próprio erro ou o seu próprio acerto, é totalmente diferente. Quando o professor fala, fica assim, "ele está falando porque está com birra, ele é professor e sabe tudo", não é a mesma coisa do que você construir o seu conhecimento", você vê, "eu errei ali, eu estou falando O.K. demais". Uma coisa é você [supervisor] chegar e falar "você está falando O.K. demais", outra coisa é eu ver eu fazendo, parece que o erro fica maior. Para mim foi uma experiência ótima.
} 
reading about speaking by Penny Ur, that small box on oral evaluation, that helped me a lot. I loved this last text about affective factors, I want to keep researching in this area $[\ldots]^{17}(\mathrm{FI}-19 / 12 / 2003)$

Lavínia, on the other hand, was not much influenced by the theory, and we can point out two reasons for that. One is that she was in the $3^{\text {rd }}$ year of the course and had not started studying about or reflecting upon teaching, and the other reason is that she had difficulty reading the texts suggested by the researchers, as stated in the following excerpt:

It was difficult to read a text up to the end [...], it was not just reading superficially. I was reading to improve my lesson, so every time I was reading, I was thinking how that text could help me or be harmful if I misread it. They were difficult readings, especially the first ones, because I didn't have any theory. I only realized that I needed theory because with the research there were texts to read ${ }^{18}$ (FI - 19/12/2003).

As far as "peer observation" is concerned, Lavínia was the most influenced. By observing their peers, both Lavínia and Penélope mentioned they learned a lot. In the final interview, Lavínia said that at first she was afraid of the criticism that might arise, but she recognized the value of such an instrument:

We are three totally different people, our class style, totally different personalities, and this is what was enriching. By watching Júnia's and Penélope's class, I learnt a lot and I think it happened to the three of us. [...] Júnia’s patience and teaching is very good for English I, which for me is very difficult. [...] It drew my attention to the way $\mathrm{P}$ is extroverted, and her classes are very dynamic and fun. The role models I had were them, but I had to take a bit of each one and put it my way

\footnotetext{
${ }^{17}$ As leituras [para esta pesquisa] foram muito boas. Eu aprendi muito mesmo. O ponto que foi uma coisa clara de como a leitura me ajudou foi a avaliação oral. Aquela leitura que a gente fez sobre speaking da Penny Ur, aquele quadrinho de avaliação oral, aquilo me ajudou demais. Esse último [texto], de aspectos afetivos, eu gostei demais, quero continuar pesquisando nessa área.

${ }^{18}$ É difícil ler [um texto] até o final [...], não era só ler superficialmente. Eu estava lendo para eu melhorar a minha aula. Então, toda vez que eu estava lendo, eu estava pensando como aquilo poderia me ajudar ou atrapalhar se eu estivesse lendo mal. Foram leituras difíceis, principalmente as primeiras, porque eu não tinha nada teórico. O que eu notei é que eu precisava de um suporte teórico, porque com a pesquisa foram aparecendo textos para eu ler.
} 
because I wouldn't be able to do it neither the way one does, nor imitating the other ${ }^{19}$ (FI - 19/12/2003).

TAB. 2 also shows that for Júnia "mentoring" had a bigger influence on the changes she mentioned, followed by "teacher experience", which equals "self-observation" and "theory". This result indicates that, before taking part in the research, Júnia had already been reflecting on her lessons and had taken advantage of mentoring since both activities guided her for future action. Out of the two research experiences which most affected Júnia, "theory" was the one she critically reflects on in the final interview:

The texts give us more security to teach, though we can't put everything into practice. I read many things about presentation, and in my classes I identify one element or another, but I notice something has failed, but I think it's worthwhile because I'm aware of these elements that should be present so that my presentation works ${ }^{20}$ (FI - 19/12/ 2003).

"Mentoring" was also one teacher education experience that Lavínia expressed in her comments, its occurrence being similar to "peers" and "input sessions". The three of them - "mentoring", "peers", and "input sessions" - are related to her teaching experience period at the language center at UFG, which was not long compared to the years she taught in other language schools. The obvious reason why these experiences outside of research were not mentioned by Penélope is that it was her first semester at the language center.

Considering the four research experiences, "self-observation" was the

\footnotetext{
${ }^{19}$ Nós somos três pessoas totalmente diferentes, o estilo de aula, personalidades totalmente diferentes, e foi o que enriqueceu, porque assistir às aulas de Júnia e Penélope, eu aprendi muito e acho que aconteceu com as três. A paciência e até a didática que a Júnia tem é muito boa para lidar com Inglês I, uma coisa que para mim é muito difícil. Já a maneira como a Penélope é extrovertida e faz muita dinâmica e muita brincadeira acabou chamando a atenção. $\mathrm{O}$ modelo que eu tive foram as duas, eu tinha que tentar pegar um pouquinho de cada e colocar do meu jeito, porque eu não conseguiria fazer nem do jeito de uma e nem imitando a outra.

${ }^{20}$ Os textos dão mais segurança na hora da prática [do ensino], embora inicialmente a gente não consiga colocar tudo em prática. Eu li um monte de coisa sobre apresentação, e nas minhas aulas eu identifico um elemento ou outro, mas eu vejo que um falhou, mas eu acho que tudo isso é válido por eu estar consciente desses elementos que deveriam estar presentes para a minha apresentação funcionar ou não.
} 
most significant one followed by "theory", "peer-observation", and "reflection". By adding the changes made from "self-observation" (22) and "peer observation" (11), it is clear that practice is more relevant in fostering teacher change than theory (13), confirming Guskey's statement that teachers are pragmatic (2002). They must see classroom events happening successfully or unsuccessfully - more than they need to read technical or theoretical books about teaching. Based on their observations of classroom events, they can make decisions about future actions.

As far as "reflection" is concerned, it did not generate much change although the three participants stated the discussions were stimulating. Penélope said the reflective sessions helped her a lot. Júnia mentioned that the sessions were productive, and the teachers had the opportunity to ask each other questions and share experience. She added that, when she watched her lessons, she could not always see how she could improve, but in the reflective sessions she was told what she could do. Lavínia said that, at the beginning, she was afraid and nervous because Penélope and Júnia were her colleagues, and it was complicated both to be criticized by colleagues and to criticize them: "I didn't feel well talking about any aspects of my colleagues' lesson." 21 Nevertheless, at the end of the research, she also recognized that this experience was important:

The exchange of information I had with both of them was very good, and it was even better in the end. In the first semester, when we started, I hadn't thought about the effect it would have later. I was still afraid of what was going to happen, of the final evaluation. In the second round, I saw I could take risks [...] because my teaching was wasn't $\operatorname{good}^{22}$ (FI - 19/12/2003).

After having analyzed the data from the perspective of sources of changes, a second analysis was made to detect what kind of change took place.

\footnotetext{
${ }^{21}$ Não me sentia bem em falar sobre um aspecto das aulas de minhas colegas.

${ }^{22}$ A troca de informação que eu tive com as duas foi muito boa e mudou mais agora no final. No primeiro semestre, quando a gente começou, eu não tinha atentado tanto para o efeito que isso ia ter mais na frente. Eu ainda estava com medo do que ia acontecer, da avaliação final. $\mathrm{Na}$ segunda rodada, é que eu vi que eu podia arriscar [...] porque do jeito que estava não estava bom.
} 


\section{Types of change}

The data reveals that changes happened both behaviorally and cognitively. According to Pennington (1995), behavioral changes are those that involve the how to do things. The teacher is worried about techniques, materials, and procedures. One example comes from Penélope's words during the final interview, when she was asked to comment on the changes that took place in her practice as a result of participating in the research:

I changed from water to wine. I was talking about that first class you observed, which was really bad, and today I can teach, do a warmer, link one thing to the other and do the steps, and make my class flow. In the past my classes were a mess, even if I had a plan, but when I taught, it didn't work the way I wanted. And I started organizing things, small things, which are not really small, like echoing, my attitude in class, [the repetition of] "Yes? No?"23 (FI - 19/12/2003).

Cognitive changes are at the level of perception (PENNINGTON, 1995); therefore, the focus is on perceptual issues, the ability to notice, understand and make good judgment about things. Verbs such as "think", "notice", "learn", "conclude", "find", and "understand" demonstrate that the teacher is reflecting. The following excerpts illustrate this [our emphasis by means of inverted commas given below]:

I have to continue with this teacher education experience I'm going through now, I have to take my plans and look at everything because if I don't have something written, a video... I made a copy of the video for myself, watched it many times, and I had to say what I could improve. It's the sort of thing I'd never done before because we don't have time. What I "noticed" is that if I don't give myself this opportunity, time will pass by and I won't realize what I have to change. I will think everything's good, that everybody can understand,

\footnotetext{
${ }^{23}$ Eu mudei da água pro vinho. Eu estava falando daquela primeira aula que você assistiu, foi muito ruim mesmo, e hoje, eu vejo como eu consigo levar a aula, o warmer, ligar uma coisa com a outra, e fazer os steps, e fazer a minha aula andar. Porque antigamente a minha aula era uma bagunça, por mais que tivesse o plano, mas na hora não saía do jeito que eu queria que saísse. E fui sistematizando mais as coisas, coisas pequenas, mas que na verdade não são pequenas, do eco, da postura em sala de aula, [a repetição] de "Yes? No?".
} 
but in fact there's a problem, even if it's a detail, small pictures, and if I don't stop to analyse, I won't notice it ${ }^{24}$ (Lavínia - 8M - 18/12/2003).

I "learnt" [with Júnia’s class] to speak more slowly in elementary levels and the presentation [the individual work which was lacking in my class], and the body language, but mainly how to deal with English ${ }^{25}$ (Penélope - 2M-23/05/2003).

Change in teachers' behavior and cognition can be reciprocal, but which one happens first is a difficult question. They change cognitively when they see something work either after observing a colleague's action and then imitating it, or trying something new in the lesson as a result of an academic or a personal theory. Our data do not allow us to affirm which kind of change happens first. However, our attention was drawn to the fact that at first Lavínia changed her practice but not her way of thinking in relation to "presentation" and "practice":

Since the beginning here, my biggest problem has been presentation. [...] Comparing my last classes, in which I tried to change the presentation, the first which I changed completely, my mentor teacher said it was OK, but I said "everything went wrong". I didn't like the lesson, [...]. Afterwards, observing the video and trying to find out what was wrong, I noticed I tried to change my style. I don't feel secure with what she [Júnia] does, that's why my presentation was a failure. I saw I have to improve many things, but I have to respect my own style. I have to present, but I give a practice activity, and during the practice I present, I can't tell one stage from the other. [...] Then I

\footnotetext{
${ }^{24}$ Essa reciclagem que eu estou fazendo agora, eu vou ter que fazer todo ano, pegar todos os meus planos e ver tudo, porque se eu não tiver uma coisa escrita, uma fita de vídeo... eu fiz uma fita para mim e ficava assistindo, que foi um trabalho que eu tinha que apresentar na volta [relatar para a supervisora]: "o que você acha que tem que melhorar?" É o tipo de coisa que em dez anos de trabalho, eu não tinha feito, porque não dá tempo. O que eu vi é que se eu não me desse esse tempo, vai passando, vai passando, e eu não vou vendo o que eu preciso melhorar e o que eu não preciso. Eu vou achando que está tudo bom, que todo mundo está entendendo, mas na verdade tem um problema, nem que seja um detalhe pequeno, da figura pequena, mas se eu não parar para ver, eu não vou notar.

${ }^{25} \mathrm{Eu}$ aprendi [com a aula de Júnia] a falar mais devagar nos níveis mais baixos e a apresentação [o trabalho individual que faltou nas minhas aulas] e a body language, mas principalmente como tratar o Inglês I.
} 
gave the same lesson to another group, but I did it differently. I did something I was used to doing, but not so slowly, and it worked. There is reading [academic theory], but there's something that is ours. There was no purpose in saying "what a beautiful theory, I'll put it into practice," but I couldn't adapt to it, it didn't work. [...] I was not going to be myself if I were presenting differently, no matter how good the theory was on paper, but I have to feel secure with it. This is what happened $^{26}(8 \mathrm{M}-18 / 12 / 2003)$.

This example shows that change in behavior does not always imply change in cognition and vice-versa. The example reveals that she changed one aspect of her teaching (presentation); however, she did not like the way she had done it, and then changed again adapting it to her own style. She ponders on the order of the steps for presenting a lesson and her teaching style.

Change, as suggested above, was also analyzed as being "technical" and "reflective", categories which were based on Bartlett's concept of a critically reflective teacher (1990). By "technical change" we mean changes that occurred because the teachers were more interested in the "technicalities of teaching" (BARTLETT, 1990). Their statements allowed us to claim they were focused on factors such as their manner, classroom management, instructions, language, steps, and pacing. "Reflective change", on the other hand, is the one in which teachers are worried about the effect of their practice on the students' affective factors or learning results, in other words, the consequences of their teaching practice for students.

${ }^{26}$ Desde o início aqui, meu problema foi a apresentação. [...] Comparando com as últimas aulas, que eu tentei mudar a apresentação, a primeira que eu mudei completamente, a supervisora disse que foi tudo bem, mas eu saí daqui e falei, "deu tudo errado". Eu não gostei da aula, [...]. Depois, vendo o vídeo e procurando onde eu errei, eu tentei mudar um estilo que é meu, assim, "eu vou seguir os passos que ele seguiu". Eu não me sinto segura com o que ela [Júnia] faz e aí minha apresentação vai por água abaixo. Eu vi que eu tenho que melhorar muita coisa, mas eu tenho que respeitar um estilo que é meu também. Eu preciso apresentar, mas eu dou uma prática, ou durante a prática, eu apresento, eu não sei diferenciar uma etapa da outra. [...] E eu dei a mesma aula na outra turma, mas eu coloquei alguma coisa diferente, que é o que eu estava acostumada, mas não tão devagar e deu resultado. Tem leitura [leitura acadêmica], mas tem uma coisa nossa. Não adiantou eu falar, "nossa, que teoria linda, eu vou colocar isso agora", mas eu não consegui me adaptar a ela, não funcionou. [...] Eu ia estar descaracterizada, eu não ia ser a Lavínia se eu estivesse apresentando de outra maneira, por melhor que ela seja no papel, mas que eu não me sinta segura com ela. Foi isso que aconteceu. 
To exemplify "technical change", we selected an excerpt of Júnia’s words about the topic "oral practice". This change is technical in the sense that it is about a segment of instruction. She compares her class with Penélope's, she comments on what oral practice was for her, and then she concludes that it can be different:

[Penélope's] class was very efficient, and the sequence of activities was very interesting because she focused a lot on speaking before moving on to writing. [...] Soon after an oral activity I propose a written one, which mingles speaking and writing. Especially because I had the idea that oral practice was freer, but I understood that it can be more controlled $^{27}(7 \mathrm{M}-07 / 11 / 2003)$.

The transcript that follows is another example of this kind of change:

After the text [that was read], I can say that "giving instructions" will be the most difficult. I've got to be clearer and quicker, but in the lesson I repeated three times ${ }^{28}$ (Lavínia - 4M - 04/07/2003).

As seen above, no overt reflection of Júnia’s and Lavínia’s actions for students is observed. The extract that follows, on the contrary, provides one illustration of "reflective change". Lavínia remarks on the relationship between the pace of the lesson and students' learning and on their perception of the fact that they are learning:

I gave four lessons after the video recording, and I noticed a very big difference $[. .$.$] . I found that when the pace was quicker, when there$ is activity all the time, it's more productive, and the students notice it because they see they've learnt and, if I ask, they know how to use

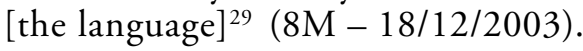

\footnotetext{
${ }^{27} \mathrm{O}$ rendimento da aula foi muito legal, a sequência das atividades muito interessante, por ter focalizado muito na fala antes de ter passado para a parte escrita. [...] Eu faço uma oral, mas depois já é uma escrita, que reúne fala e escrita. Até pela ideia que eu tinha de prática oral ser mais livre, mas eu vi que dá pra fazer mais controlada. ${ }^{28}$ Depois do texto [que foi lido], o que vai me dar mais trabalho é giving instructions. Eu tenho que ser mais clara e passar mais rapidamente, mas na aula eu repeti três vezes.

${ }^{29}$ Foram quatro aulas depois da gravação, e eu notei uma diferença muito grande [...]. Então, eu achei que no final, quando o ritmo estava mais acelerado, quando tem atividade o tempo todo, rende mais, e ele percebe isso, porque ele vê que ele aprendeu, e depois se eu perguntar, ele sabe usar.
} 
Other examples of what we mean by "reflective change" follow:

I brought up the topic of accent because, though [the book] English File is British, I can't teach British English, and it's always a conflict, but I think they accept this difference naturally. [...] I think I have to study a lot because it's a matter of cultural acceptance and we should avoid discrimination against one accent or another ${ }^{30}$ (Júnia $-4 \mathrm{M}-$ 4/7/2003).

After I watched my first class and read the texts, [I thought], "How could I reduce my talking time to let students speak, but in English?" because, in levels V and VI, it's easy, but I am teaching [level] IV now. [...] However, there's now another problem. To what extent will I have to control my vocabulary? Something I hadn't thought of before. [...] "I'm in level IV. What vocabulary do they have and how can they understand what I'm saying without the need for translation?"31 (Lavínia - 5M - 03/ 10/2003).

These two types of change were quantified and the result can be seen in TAB. 3. We believe this analysis is relevant because it shows the level of reflection reached by each participant compared to the technical changes. In effect, if changes are just technical or solely focus on what the teacher does, it may not produce significant learning results, which, after all, is what teaching is all about.

\footnotetext{
${ }^{30}$ Eu levantei a questão do sotaque por eu não conseguir ensinar o inglês britânico, embora o [livro] English File seja britânico, o que gera conflito sempre, mas eu acho que eles aceitam muito naturalmente essa diferenciação. [...] Então, eu acho que eu tenho que estudar muito, porque é questão de aceitação cultural e para que não tenha tanta discriminação entre uma pronúncia e outra.

${ }^{31}$ Depois eu assisti à minha primeira aula que foi gravada e os textos que eu fiz a leitura: "Como que eu poderia diminuir a minha fala para deixar que eles falassem, também, e que essa fala deles fosse em inglês, também?" Porque no [nível] V e no [nível] VI é mais fácil; agora eu estou com o [nível] IV. [...] Só que entrou um outro problema. Até que ponto que eu vou ter que dosar meu vocabulário também? Que era uma coisa que eu não tinha atentado antes para isso. [...] "Eu estou no Inglês IV. Que vocabulário que eles já têm e como que eles podem entender o que eu estou falando e que eles não precisam da tradução para me entender?”.
} 
TABLE 3

Number of "technical" and "reflective changes" for each participant

\begin{tabular}{l|c|c|c|c}
\hline & Penélope & Lavínia & Júnia & Total \\
\hline Technical changes & 10 & 5 & 6 & 21 \\
Reflective changes & 10 & 20 & 9 & 39 \\
\hline
\end{tabular}

As a whole, the results of this analysis show that there were more "reflective changes" than "technical changes" for Júnia and Lavínia. Penélope’s number of "technical changes" (10) was twice as many as Lavínia's (5) and a little more than twice as many as Júnia's (6). This, somehow, demonstrated a normal tendency as she is the least experienced teacher. Less experienced teachers tend to focus, primarily, on their performance as teachers and on procedural aspects such as techniques and materials, as shown in Richards, Ho, and Giblin (1996). Lavínia, the most experienced teacher, showed she was more reflective. The reason for that may have been that she had already gone through years of teaching practice and had adapted to different school requirements and so had already gained some confidence. Perhaps, her teaching practice had never been questioned until then. She was beyond the procedural aspects phase, though not yet totally satisfied with instructional practice as she saw it with the research. The data indicate that she included the students while reflecting on her actions. She was worried more about how her teaching affected the students.

Júnia’s data reveal her declared changes were more "reflective" (9) than "technical" (6). Although she was not the most experienced, she had more theory and was further ahead in her undergraduate course. The path she has taken since she started studying at university seemed to be more guided or instructed considering the sources of change detected in this research study.

\section{Final thoughts}

The aims of this study were to examine the kind of experiences which caused the declared changes, the number of declared changes caused by these experiences for each participant, and the types of declared changes. In all, eight experiences were detected, four research experiences ("self-observation", "peerobservation", "theory" and "reflection") and four experiences outside of the research ("mentoring", "peers", "input sessions", and "teacher experience").

According to the results, Penélope and Lavínia were the participants who were most affected by the research while Júnia was the least affected. This 
result may be due to the fact that Penélope was a teacher who had never experienced teaching the four skills in a communicative way, and Lavínia was an experienced teacher who had always taught by routine, and had not had an opportunity to reflect (in Dewey's term) about her teaching practice, as she herself puts it:

It's the sort of thing that I hadn't done in ten years of work due to a lack of time. What I saw is that if I didn't give myself this time, things would go on and I'd not notice what I had to improve. I would think everything was $\mathrm{OK}[\ldots]$, but it wasn't OK. ${ }^{32}$

Júnia, on the other hand, was the least influenced by the research probably because, though she had little experience in teaching, she was doing the $5^{\text {th }}$ year of the English teacher education course and was doing some disciplines covering teaching theory and practice. It seemed she had already reflected on most topics discussed, either individually, as a result of her teacher experience, or collaboratively, as a result of mentoring, theoretical reading and peer example.

Considering the four research experiences, class observation was clearly demonstrated in the research as a powerful instrument to foster reflection and change, indicating that teacher education groups or programs may be more productive if they start from teachers' classroom events instead of theoretical texts. Besides, out of the eight experiences mentioned by the participants only two do not belong to the realm of practice ("theory" and "input sessions"), confirming our last statement. Having their practice as a stepping stone is a way of personalizing teacher development work since much has been said about the singularity of teaching contexts and the need for teachers to problematize their pedagogical practice and become aware of the possibility for change so that better learning results may be achieved.

As far as the relationship between cognitive and behavioral change is concerned, we found that both took place, and, though we do not know which one happened first, one may have led to the other. This conclusion is supported by an event that constituted an exception to what we perceived as this natural tendency, manifested when Lavínia changed her practice concerning presentation (influenced by Júnia) without changing her thinking about it. Her comments showed she was so disturbed that she changed her actions again

${ }^{32}$ É o tipo de coisa que em dez anos de trabalho eu não tinha feito porque não dá tempo. O que eu vi é que se eu não me desse esse tempo, vai passando, vai passando, e eu não vou vendo o que eu preciso melhorar e o que eu não preciso. Eu vou achando que está tudo bom [...], mas na verdade tem um problema. 
to match them to her cognition, that is, to what was in keeping with her personal theories. All the other changes stated by the participants seemed to have been a reciprocal process between behavior and beliefs (FULLAN, 1991).

Concerning "technical" and "reflective" changes, this study shows that the less experienced teacher instituted more "technical changes" and the more experienced teacher adopted more "reflective changes". It means that teachers, as they gain experience, become less concerned about the technicalities of teaching and more concerned about the students, which is one of the first steps to critical reflection. We cannot claim, from the data used to illustrate the discussion held here, that our participants achieved the level of criticism referred to by Bartlett (1990), the level in which teachers will exercise control over their actions and notice how these actions are part of the historical, social, and cultural context.

Transformation does not depend only on teachers, but they can be the first proponents of change, despite the contrary forces from the system. Wanting to surpass themselves and better their practice for the benefit of their students is a first step. The second is being aware of what they do and what they can do to help their students produce good results. We hope this article showed one way that all this can happen: observing ones' own or a peer's practice and reflecting upon it. Maturity comes not only with years of classroom experience but also with opportunities created to talk about what happens in the classroom and why.

\section{References}

BARTLETT, L. Teacher development through reflective teaching. In: RICHARDS, J. C.; NUNAN, D. (Ed.). Second language teacher education. Cambridge: Cambridge University Press, 1990. p. 202-214.

BORG, S. Teacher cognition in language teaching: a review of research on what language teachers think, know, believe, and do. Language Teaching, v. 36, p. 81109, 2003.

BREEN, M. P.; HIRD B.; MILTON, M.; OLIVER, R.; THWAITE, A. Making sense of language teaching: teachers' principles and classroom practices. Applied Linguistics, v. 22, n. 4, p. 470-501, 2001.

DEWEY, M. How we think. New York: Dover, [1910] 1997.

FULLAN, M. G. Professional development of educators. In: FULLAN, M. G., The new meaning of educational change. New York: Teachers College Press, 1991. p. 315-344. 
GATBONTON, E. Investigating experienced ESL teachers' pedagogical knowledge. The Modern Language Journal, v. 83, n. 1, p. 35-50, 1999.

GUSKEY, T. R. Professional development and teacher change. Teachers and Teaching: theory and practice, v. 8, n. 3/4, p. 381-391, 2002.

JOHNSON, K. E. Learning to teach: instructional actions and decisions of preservice ESL teachers. TESOL Quarterly, v. 26, n. 3, p. 507-535, 1992.

PENNINGTON, M. The teacher change cycle. TESOL Quartely, v. 24, n. 1, p. 705-731, 1995.

PESSOA, R. R.; SEBBA, M. A. Y. Mudança nas teorias pessoais e na prática pedagógica de uma professora de inglês. In: BARCELOS, A. M.; VIEIRAABRAHÃO, M. H. (Org.). Crenças e ensino de línguas: foco no professor, no aluno e na formação de professores. Campinas, Pontes, 2006. p. 43-64.

RICHARDSON, V. How teachers change: What will lead to change that most benefits student learning? Focus on Basics 2, 1998. Disponível em: <http:// www.ncsall.net/?id=395>. Acesso em: 1 fev. 2006.

RICHARDS, J. Teacher beliefs and decision making. In: RICHARDS, J. C. Beyond training. Cambridge: Cambridge University Press, 1998. p. 65-85.

RICHARDS, J. C.; HO, B.; GIBLIN, K. Learning how to teach in the RSA Cert. In: FREEMAN, D.; RICHARDS, J. C. (Ed.). Teacher learning in language teaching. Cambridge: Cambridge University Press, 1996. p. 242-259.

SIMÃO, A. M. V.; CAETANO, A. P.; FLORES, M. A. Contextos e processos de mudança dos professores: uma proposta de modelo. Educação e Sociedade, v. 26, n. 90, p. 173-188, 2005.

SMYTH, J. Teachers as collaborative and critical learners. In: SMYTH, J. Teachers as collaborative learners: challenging dominant forms of supervision. Buckingham: Open University Press, 1991. p. 83-104.

TARDIF, M.; RAYMOND, D. Saberes, tempo e aprendizagem no trabalho do magistério. Revista Educação e Sociedade, v. 21, n. 73, p. 209-244, 2000.

Recebido em dezembro de 2007. Aprovado em maio de 2008. 